\title{
Final Report FUS325
}

\section{Topic : $\quad$ Usability of MR guided lung cancer ablation, using saline flooded lung}

Period : $\quad$ June $2014-$ Sept 2015

Submitted by:

Gera, $28^{\text {th }}$ August 2015

\section{PD Dr. med. Thomas Lesser, PI}

Chief Physican of Thoracic \& Vacular Surgery, SRH Wald-Klinikum Gera, Gera Germany

\section{M.sc. Frank Wolfram, CoI}

Medical physicists; Thoracic \& Vacular Surgery, SRH Wald-Klinikum Gera, Gera Germany
A. Status:

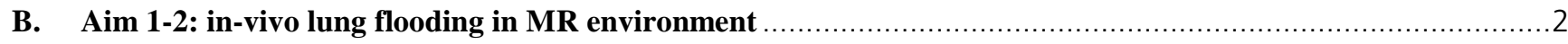

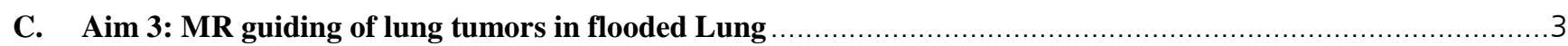

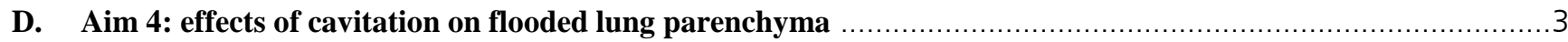
E. Summary

\section{A. Status:}

LUNG FLOODING GENERATES GAS FREE SALINE-PARENCHYMA COMPOUND WITHOUT DAMAGING THE LUNG (1). RECENTLY OUR WORK SHOWED THAT UNDER LUNG FLOODING ULTRASOUND GUIDING (2) AND HIFU ABLATION OF LUNG CANCER (3) CAN BE PERFORMED. THIS RESEARCH PROJECT WAS AIMED TO DEVELOP A LARGE ANIMAL MODEL FOR LUNG FLOODING IN MR ENVIRONMENT. TOWARDS FUS LUNG CANCER ABLATION, THIS MODEL WILL HELP TO DEMONSTRATE THE USABILITY OF MR GUIDING AND THERMOMETRY IN FLOODED LUNG IN FUTURE STUDIES. ADDITIONAL THE CAVITATION THRESHOLD IN LUNG PARENCHYMA WAS ESTIMATED USING FLOODED HUMAN LUNG LOBES EX-VIVO. IN AN ADDITIONAL HIFU PART, POSSIBLE SIDE EFFECTS OF CAVITATION IN FLOODED LUNG WERE INVESTIGATED.

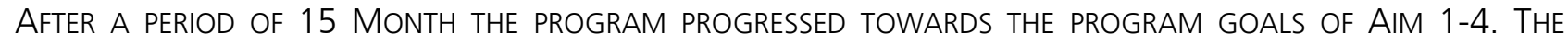
CURRENT WORK PACKAGES ACHIEVED FOLLOWING STATUS:

$>$ LUNG-FLOODING WAS PERFORMED SUCCESSFUL ON A PORCINE MODEL IN MR IN 6 OF 6 ANIMALS.

> FAST T1 TSE AND GRE AS WELL AS T2 HASTE SEQUENCES WAS APPLIED IN-VIVO AFTER UNILATERAL LUNG FLOODING. MRI ALLOWED COMPLETE EXAMINATION OF THE FLOODED LUNG. LUNG PARENCHYMA CAN BE DISCRIMINATED FROM BRONCHIAL AND VASCULAR STRUCTURE.

> HUMAN LUNG LOBES CONTAINING LUNG CANCER (NSCLC) AND LUNG METASTASES COULD BE IMAGE BY MRI. IN ALL CASES THE TUMOR COULD BE WELL DISCRIMINATED FROM LUNG PARENCHYMA AND BRONCHIAL STRUCTURE.

THE CAVITATION THRESHOLD IN FLOODED LUNG WAS EVALUATED USING SUB-HARMONIC PCD AND B-MODE IMAGING. WITHIN THIS, A CAVITATION THRESHOLD FOR PCD OF $1.250 \mathrm{~W} / \mathrm{cm}^{2}$ WAS ESTIMATED. AN EROSIVE EFFECT ON LUNG PARENCHYMA REQUIRED FOCAL INTENSITIES ABOVE $12.000 \mathrm{~W} / \mathrm{cm}^{2}$. 


\section{B. Aim 1-2: in-vivo lung flooding in MR environment}

In a first trail period, lung flooding with two animals ("Landschwein", female ca. 35-65kg) were performed with MR compatible equipment in a surgery room. Then five pigs where flooded in-vivo in MR (TRIO-Prisma 3T, Siemens AG, Erlangen, Germany) (Fig.1a). Gas free flooding of the left lung wing was achieved in all animals and maintained for 60-90 min before re-ventilation. Imaging was performed using T1 TSE, GRE(VIBE) and T2(HASTE) (Fig. 1b) sequences under manual respiratory gating. An intra-pulmonary lesion was simulated using balloon catheter (6F, Edwards LLC, Irvine, USA) filled with contrast agent (Fig.1d).

Fig. 1a porcine model during flooding in MRI

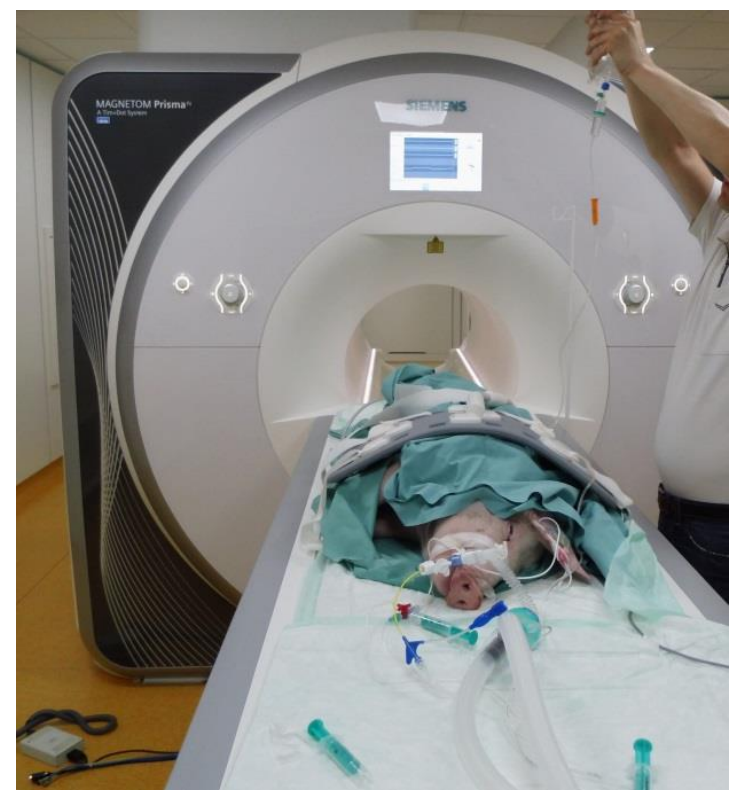

Fig. 1c coronal T1 phase map of porcine model during flooding

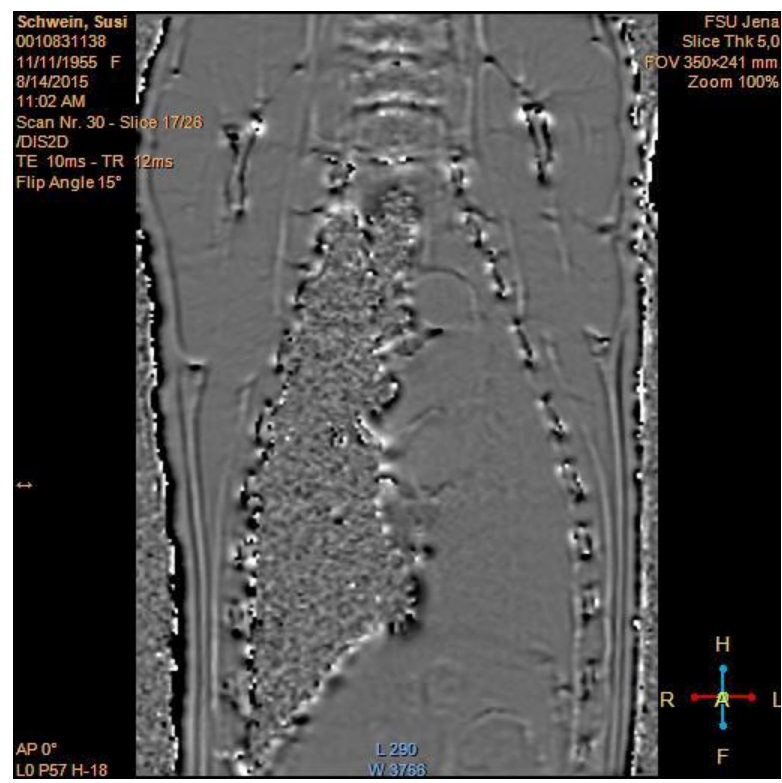

Fig. 1b T2w image in-vivo of flooded (I) \& ventilated (r) lung

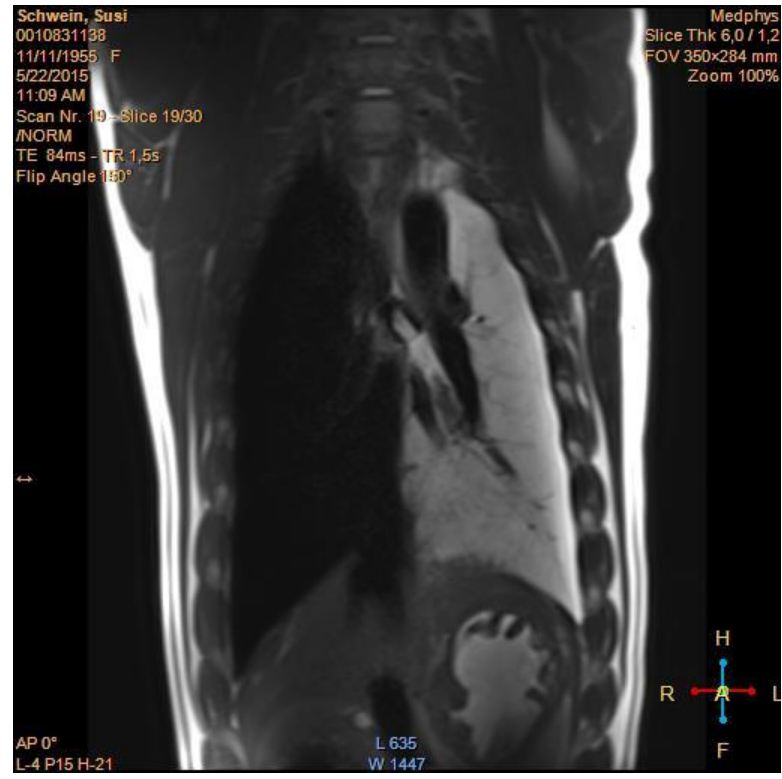

Fig. 1d simulated intrapulmonary lesion in flooded lung

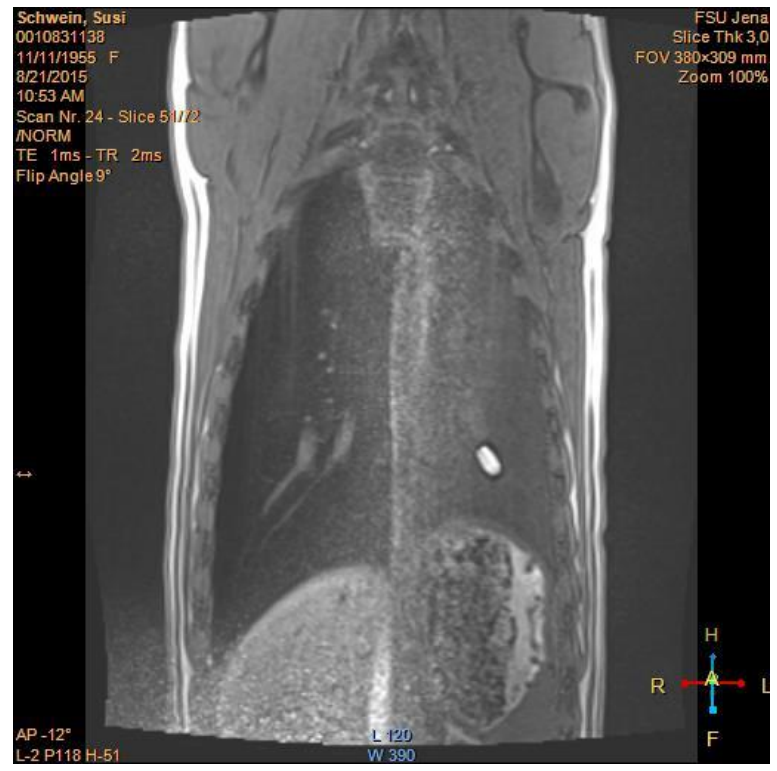




\section{Aim 3: MR guiding of lung tumors in flooded Lung}

Human lung lobes containing NSCLC and Metastases were flooded following intra-surgical atelectasis. MR (Achieva 1,5T, Phillips, Netherlands) images were acquired ex-vivo using T1_FFE and T2_SSSh sequences. All tumors could be visualized well in flooded lung parenchyma. In summary lung cancer appear hyperintense in T1_w (Fig.2b) and hypointense in T2_W (Fig.2a) images. All tumors and metastases could be detected by MR imaging and discriminated from flooded lung. Therefore Guidance of HIFU for FUS treatment of lung tumors appears feasible in flooded lung.

Fig. 2a T2w image of a peripheral NSCLC in flooded Lung

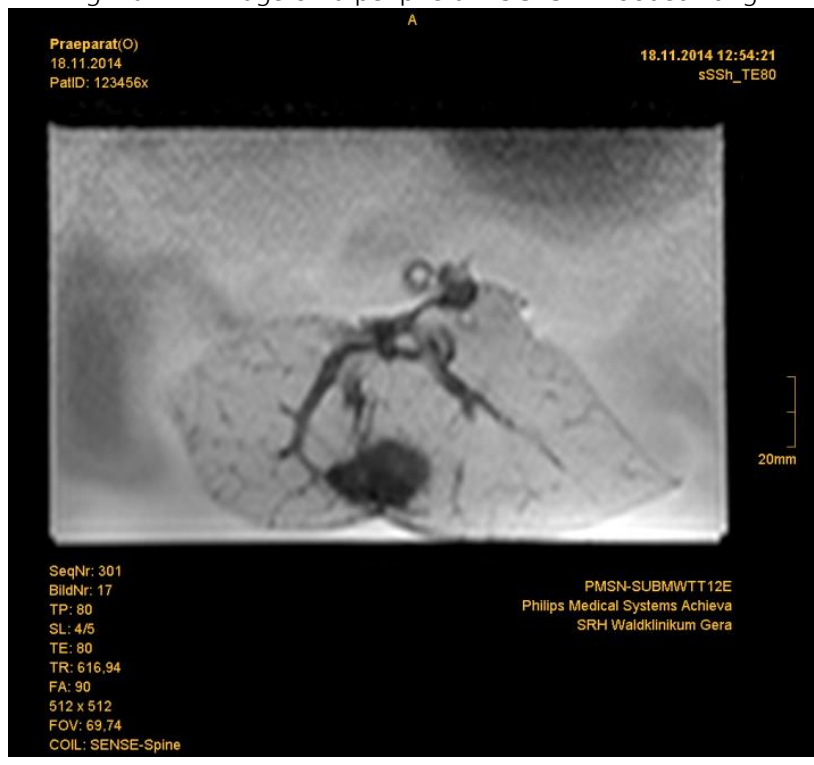

Fig. 2b T1w image of Lung Metastasis from CRC

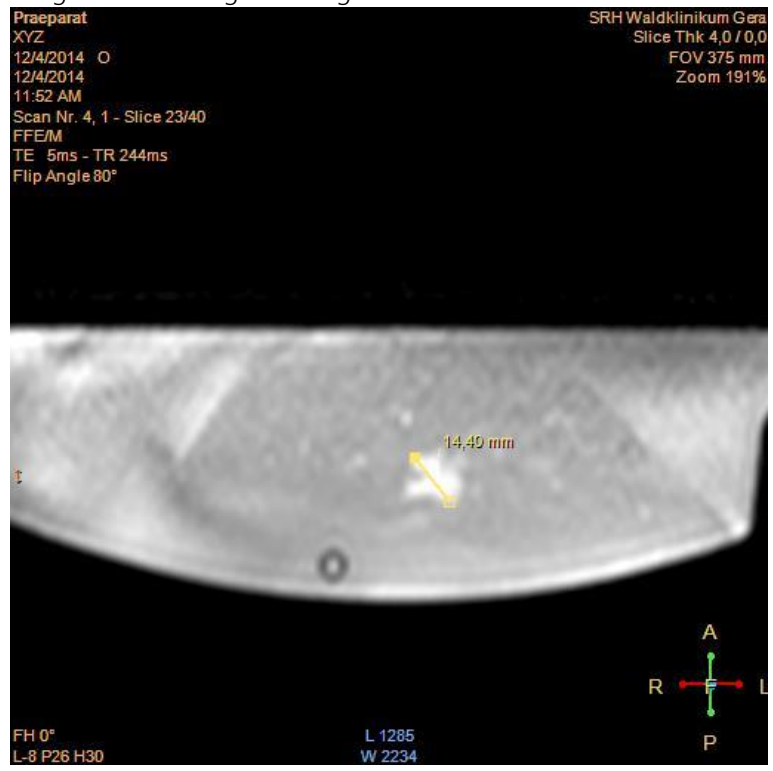

\section{Aim 4: effects of cavitation on flooded lung parenchyma}

A setup for exposing HIFU into ex-vivo flooded human lung lobes and monitoring cavitation by Ultrasound B Mode imaging and passive cavitation detection were build (see 6month report). Cavitation threshold is determined by counting sub-harmonic amplitudes during PCD sampling and tissue erosion events monitored by B-Mode images. A PCD cavitation threshold was found to be $1.250 \mathrm{~W} / \mathrm{cm}^{2}$. Tissue erosion in flooded lung parenchyma requires intensities above $12.000 \mathrm{~W} / \mathrm{cm}^{2}$. Those erosive levels are fare above intensities required for FUS ablation of lung cancer tissue (3).

Fig.3a probability of cavitation by PCD with intensity

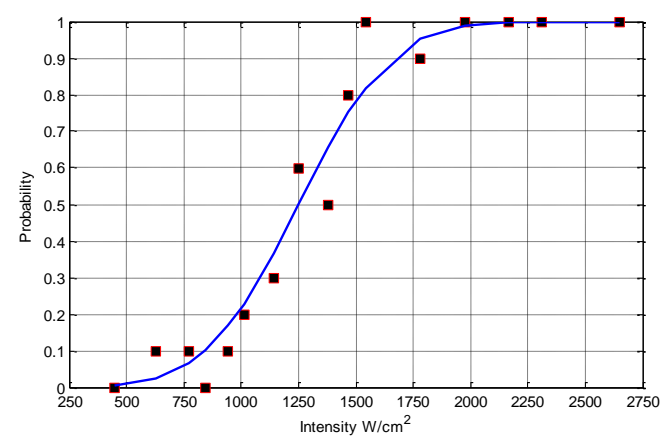

Fig.3b Lung parenchyma erosion resulting in echoless structure after HIFU exposure of $12.000 \mathrm{~W} / \mathrm{cm}^{2}$

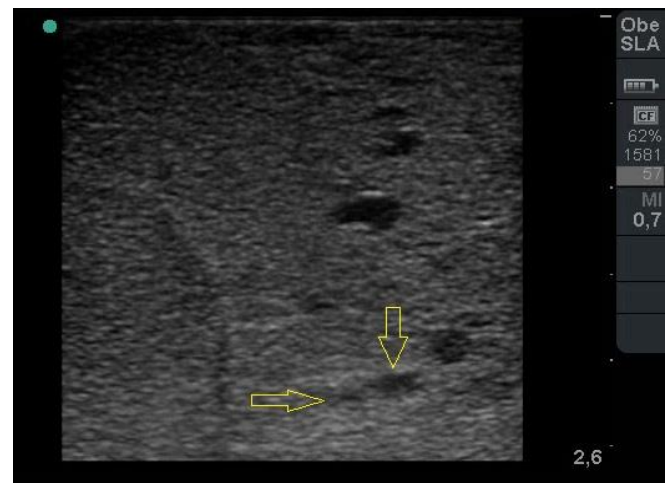




\section{E. Summary}

All major aims of the project were achieved. Within this, a large animal model for lung flooding was developed, which is the essential milestone to enable future human MRgFUS lung cancer studies. MR guidance of all common lung tumor entities is feasible and showed a clear demarcation of flooded lung and tumors in T1 and T2 fast GRE and TSE sequences.

A benign tumor was not available during the trail period. One secondary aim, investigating the usability of PRFS thermometry, could not be achieved, since available thermometry exam cards were not compatible with the current MR Release. However analysis of in-vivo GRE phase maps indicate that in flooded Lung the phase stability is as good as in abdominal organs or muscle tissue (Fig.1c). Future work should be dedicated to MR thermometry in flooded lung.

Cavitation occurs in flooded lung as expected, but not causing erosive damage at intensities required for ablation of cancer tissue.

\section{Citited Works}

(1) Wolfram, F, H Schubert, S Bischoff, AND TH LesSER. "EFFECT OF LUNG FlOOdING AND HIGH-INTENSITY FOCUSED ULTRASOUND ON LUNG TUMOURS: AN EXPERIMENTAL STUDY IN AN EX VIVO HUMAN CANCER MODEL AND SIMULATED IN VIVO TUMOURS IN PIGS." EUR J MED RES 19, NO. 1 (2014).

(2) LESSER, T, H SCHUBERT, S BISCHOFF, AND F WOLFRAM. "LUNG FLOODING ENABLES EFFICIENT LUNG SONOGRAPHY AND TUMOUR IMAGING IN HUMAN EX VIVO AND PORCINE IN VIVO LUNG CANCER MODELS." EUROPEAN JOURNAL OF MEDICAL RESEARCH 18, NO. 23 (2013).

(3) WOLFRAM, F, J REICHENBACH, AND TH LESSER. "AN EX VIVO HUMAN LUNG MODEL FOR ULTRASOUND GUIDED HIFU THERAPY USING LUNG FLOODING." ULTRASOUND IN MED \& BIOL 40, NO. 3 (2013): 496-503. 